\title{
A CASE STUDY COMPARISON OF LANDFIRE FUEL LOADING AND EMISSIONS GENERATION ON A MIXED CONIFER FOREST IN NORTHERN IDAHO, USA
}

\author{
Josh Hyde ${ }^{*}$, Eva K. Strand ${ }^{1}$, Andrew T. Hudak ${ }^{2}$, and Dale Hamilton ${ }^{3}$ \\ ${ }^{1}$ University of Idaho College of Natural Resources \\ Department of Forest, Rangeland, and Fire Sciences, \\ 975 West $6^{\text {th }}$ Street, Moscow, Idaho 83844, USA \\ ${ }^{2}$ USDA Forest Service, Rocky Mountain Research Station, \\ 1221 South Main Street, Moscow, Idaho 83843, USA \\ ${ }^{3}$ Northwest Nazarene University, Mathematics and Computer Science Department, \\ 623 South University Boulevard, Nampa, Idaho 83686, USA \\ *Corresponding author: Tel.: +1-206-473-1979 e-mail: jhyde@uidaho.edu
}

\section{ABSTRACT}

The use of fire as a land management tool is well recognized for its ecological benefits in many natural systems. To continue to use fire while complying with air quality regulations, land managers are often tasked with modeling emissions from fire during the planning process. To populate such models, the Landscape Fire and Resource Management Planning Tools (LANDFIRE) program has developed raster layers representing vegetation and fuels throughout the United States; however, there are limited studies available comparing LANDFIRE spatially distributed fuel loading data with measured fuel loading data. This study helps address that knowledge gap by evaluating two LANDFIRE fuel loading raster options-Fuels Characteristic Classification System (LANDFIRE-FCCS) and Fuel Loading Model (LANDFIRE-FLM) layers - with measured fuel loadings for a 20000 ha mixed

\section{RESUMEN}

El uso del fuego como herramienta de manejo de tierras es bien reconocido por sus beneficios ecológicos en varios ecosistemas naturales. Para continuar con el uso del fuego y a su vez cumplir con las regulaciones referidas a la calidad del aire, los gestores de tierras deben frecuentemente cumplir con tareas de modelado de emisiones durante el proceso de planificación de las quemas. Para alimentar tales modelos, el programa denominado Landscape Fire and Resource Management Planning Tools (LANDFIRE) ha desarrollado capas raster, que representan vegetación y combustibles a lo largo de todos los EEUU; desde luego, son limitados los estudios disponibles que puedan comparar los datos de carga de combustibles espacialmente distribuidos derivados del LANDFIRE, con datos similares producto de mediciones de carga de combustible en el terreno. Este estudio ayuda a dilucidar este vacío en el conocimiento mediante la evaluación de carga de combustible usando dos opciones del programa LANDFIRE—el Fuels Characteristic Classification System (LANDFIRE-FCCS) y el Fuel Loading Model (LANDFIRE-FLM) layers- 
conifer study area in northern Idaho, USA. Fuel loadings are compared, and then placed into two emissions models - the First Order Fire Effects Model (FOFEM) and Consume-for a subsequent comparison of consumption and emissions results. The LANDFIRE-FCCS layer showed $200 \% *$ higher duff loadings relative to measured loadings. These led to $23 \%$ higher total mean total fuel consumption and emissions when modeled in FOFEM. The LANDFIRE-FLM layer showed lower loadings for total surface fuels relative to measured data, especially in the case of coarse woody debris, which in turn led to $51 \%$ lower mean total consumption and emissions when modeled in FOFEM. When the comparison was repeated using Consume model outputs, LANDFIRE-FLM consumption was $59 \%$ lower relative to that on the measured plots, with 58\% lower modeled emissions. Although both LANDFIRE and measured fuel loadings fell within the ranges observed by other researchers in US mixed conifer ecosystems, variation within the fuel loadings for all sources was high, and the differences in fuel loadings led to significant differences in consumption and emissions depending upon the data and model chosen. The results of this case study are consistent with those of other researchers, and indicate that supplementing LANDFIRE-represented data with locally measured data, especially for duff and coarse woody debris, will produce more accurate emissions results relative to using unaltered LANDFIRE-FCCS or LANDFIRE-FLM fuel loadings. Accurate emissions models will aid comparados con la medición de la carga para 20000 ha de un área de bosques mixtos de coníferas en el norte de Idaho, EEUU. Las cargas de combustibles fueron comparadas, y luego ubicadas dentro de dos modelos-el First Order Fire Effects Model (FOFEM) y el Consume-para su subsecuente comparación de los resultados del consumo de combustibles y sus emisiones. El LANDFIRE-FCCS mostró una estimación $200 \%$ * superior en la carga del mantillo comparado con la carga medida a campo. Esto llevó a un valor $23 \%$ más alto en la media total de consumo y emisiones del combustible cuando fue modelado mediante el modelo FOFEM. El modelo LANDFIRE-FLM layer mostró menores cargas para combustibles de superficie relativo a datos medidos a campo, especialmente en el caso de restos de combustible leñoso grueso (coarse woody debris), que a su vez llevó a un $51 \%$ menos en el consumo y emisiones promedio cuando fueron modeladas por el modelo FOFEM. Cuando la comparación fue repetida usado el Consume model outputs, el consumo estimado por el LANDFIRE-FLM fue un $59 \%$ menor en relación a lo determinado en las parcelas medidas, con un $58 \%$ menos que las emisiones modeladas. Aunque ambos modelos de LANDFIRE y las cargas efectivamente medidas se ubican dentro de los rangos observados por otros investigadores en los ecosistemas mixtos de coníferas de los EEUU, la variación dentro de las cargas de combustible determinadas por las distintas fuentes fue alta, y las diferencias en carga de combustible llevan a diferencias significativas en consumo y emisiones, dependiendo éstos del modelo elegido. Los resultados de este estudio de caso son consistentes con aquellos obtenidos por otros investigadores, e indican que suplementando datos de LANDFIRE con datos locales obtenidos de mediciones a campo, especialmente para el mantillo y restos de combustible leñoso grueso, producirá resultados de consumo y emisiones más precisos que aquellos que usan solamente datos de carga provistos por LANDFIRE-FCCS o LANDFIRE-FLM. Los modelos de emisiones preci- 
in representing emissions and complying with air quality regulations, thus ensuring the continued use of fire in wildland management. sos ayudarán a representar emisiones y a cumplir con las regulaciones sobre la calidad del aire, de manera de asegurar el uso continuado del fuego en el manejo de áreas naturales.

Keywords: coarse woody debris, duff, fire effects, fuel loading models, Fuels Characterization Classification System, LANDFIRE

Citation: Hyde, J., E.K. Strand, A.T. Hudak, and D. Hamilton. 2015. A case study comparison of LANDFIRE fuel loading and emissions generation on a mixed conifer forest in northern Idaho, USA. Fire Ecology 11(3): 108-127. doi: 10.4996/fireecology.1103108

\section{INTRODUCTION}

The use of fire as a land management tool is widely recognized for its ecological benefits, and as a historic disturbance that has driven succession across many ecosystems (Agee 1996, Hardy and Arno 1996, Rothman 2005). While fire science and policy has advanced in the last 50 years to better allow for the use of fire in managing wildlands (van Wagtendonk 2007), increasingly stringent air quality regulations (US EPA 1990, Hardy et al. 2001, US EPA 2015,) and an increased awareness of the health impacts from smoke (Liu et al. 2015) can make the use of fire as a management tool difficult. In a recent United States survey, prescribed fire practitioners expressed that smoke and air quality issues are the third greatest impediment to prescribed burning, following low work capacity and unfavorable weather conditions (Melvin 2012). To continue using fire as a management tool, land managers must plan to meet management objectives, while also limiting the impact of smoke on public health and keeping smoke levels within regulatory thresholds (NWCG 2014). Such planning may often require the use of models to determine the quantity of emissions generated by fire; these models require many pieces of information, including expected fire size, fuel loading characteristics, and fuel consumption. Of these, fuel loading has been identified as the most critical step in obtaining accurate smoke predictions (Drury et al. 2014). Unfortunately, in many areas there may be little or no measured data on fuel loading; this creates a major difficulty in estimating fuel consumed and emissions produced.

To address the lack of fuel loading information in planning, geospatial Fire Effects Fuel Model (FEFM) layers developed by the Landscape Fire and Resource Management Planning Tools (LANDFIRE) program are often used. LANDFIRE data layers were developed for the contiguous United States, Alaska, and Hawaii to provide consistent geospatial data describing the vegetation type, structure, fuel loading, and disturbances, regardless of land ownership boundaries (Rollins 2009). LANDFIRE is principally intended to inform management and planning decisions made by land management agencies in the United States. It is also the only resource available that provides the geospatial information outlined above across as wide an area as the continental US. To populate models for smoke production, LANDFIRE FEFMs describe fuel loading for duff, litter, woody fuels from timelag size classes ranging from one hour $(\leq 0.6 \mathrm{~cm})$ to 1000 hours $(\geq 7.62 \mathrm{~cm})$, and live herb and shrub loading. Currently, there are two FEFM choices available through LANDFIRE: one represents fuel loading based on the Fuel Loading Model (FLM) categories developed by Lutes et al. (2009), and the other based on Fuels Characteristics Classification System (FCCS) categories developed by Ottmar et al. (2007). Both methods are derived 
from extensive measured datasets; however, FCCS is stratified to represent fuel loading by vegetation type (Ottmar et al. 2007), while FLM is stratified to represent fuel loadings by their potential fire effects (Lutes et al. 2009). The two LANDFIRE FEFMs are different not only in how they stratify fuels, but also in their reported fuel loadings.

There have been few studies that detail the differences between these two LANDFIRE FEFMs. One study evaluated their mapping performance across the western United States (Keane et al. 2013), and another compared their loadings and resulting emissions as part of a broader comparison of factors affecting smoke predictions in Washington, USA (Drury et al. 2014). When Keane et al. (2013) compared fuel loading and mapping accuracy of FCCS and FLM LANDFIRE layers throughout the western United States to data from the Forest Inventory and Analysis (FIA) program, they found poor correlations between FIA and LANDFIRE represented loadings, mainly due to the high variability in fuel loadings. Drury et al. (2014) compared FLM and FCCS FEFM data with other local datasets and found the landscape fuel loadings to range from 2.7 million $\mathrm{Mg}$ to 8.8 million $\mathrm{Mg}$ for their research area in Washington, USA, depending on which fuel loading dataset they used.

Studies such as these are extremely valuable for documenting the complexity and variation within fuel loading data, and identifying the importance and challenges of applying FEFM fuels data to model emissions. Our study builds on the few evaluations of LANDFIRE FEFMs to date by comparing FEFM surface fuel loading with measured fuel loadings, and using these loadings in two popular consumption and emissions models - the First Order Fire Effects Model (FOFEM) and Consume - to compare the resulting differences in fuel consumption and emissions production, while holding the site and environmental conditions constant. This provides insight into the degree of fuel loading differences possible at smaller scales relative to the national or sub-regional scales that LANDFIRE was developed to represent. Yet this 20000 ha area is large enough to fall within the range of fire management units that land managers are tasked to manage (USDI NPS 2005, USDA FS 2008). We compared duff, litter, herb, shrub, and woody fuel loadings measured in forest inventory plots to those shown on both LANDFIRE Fuel Loading Models (LANDFIRE-FLM) and LANDFIRE Fuels Characterization Classification System (LANDFIRE-FCCS) maps. Subsequent differences in modeled consumption and emissions using FOFEM and Consume are reported.

\section{METHODS}

\section{Study Area}

To evaluate potential differences in predicted fuel loadings and fire effects, we selected a 20000 ha study area centered on Moscow Mountain in Latah County, Idaho, USA (Figure 1). The mountain lies in the Palouse Range of northern Idaho, with elevations ranging from $770 \mathrm{~m}$ to $1516 \mathrm{~m}$. Moscow Mountain is dominated by mixed conifer forest tree species including ponderosa pine (Pinus ponderosa C. Lawson var. scopulorum Engelm.), Douglas-fir (Pseudotsuga menziesii [Mirb.] Franco var. glauca [Beissn.] Franco), grand fir (Abies grandis [Douglas ex D. Don] Lindl.), western red cedar (Thuja plicata Donn ex D. Don), western hemlock (Tsuga heterophylla [Raf.] Sarg.), and western larch (Larix occidentalis Nutt.). Ponderosa pine and Douglas-fir habitat types occur on the xeric southern and western aspects, grand fir and cedar-hemlock habitat types occur on the mesic northern and eastern aspects (Cooper et al. 1991). The majority of the land is owned by private timber companies, private non-commercial landowners, and public land holdings. Recent disturbances recorded between 2003 and 2009 were predominantly the result of forest man- 


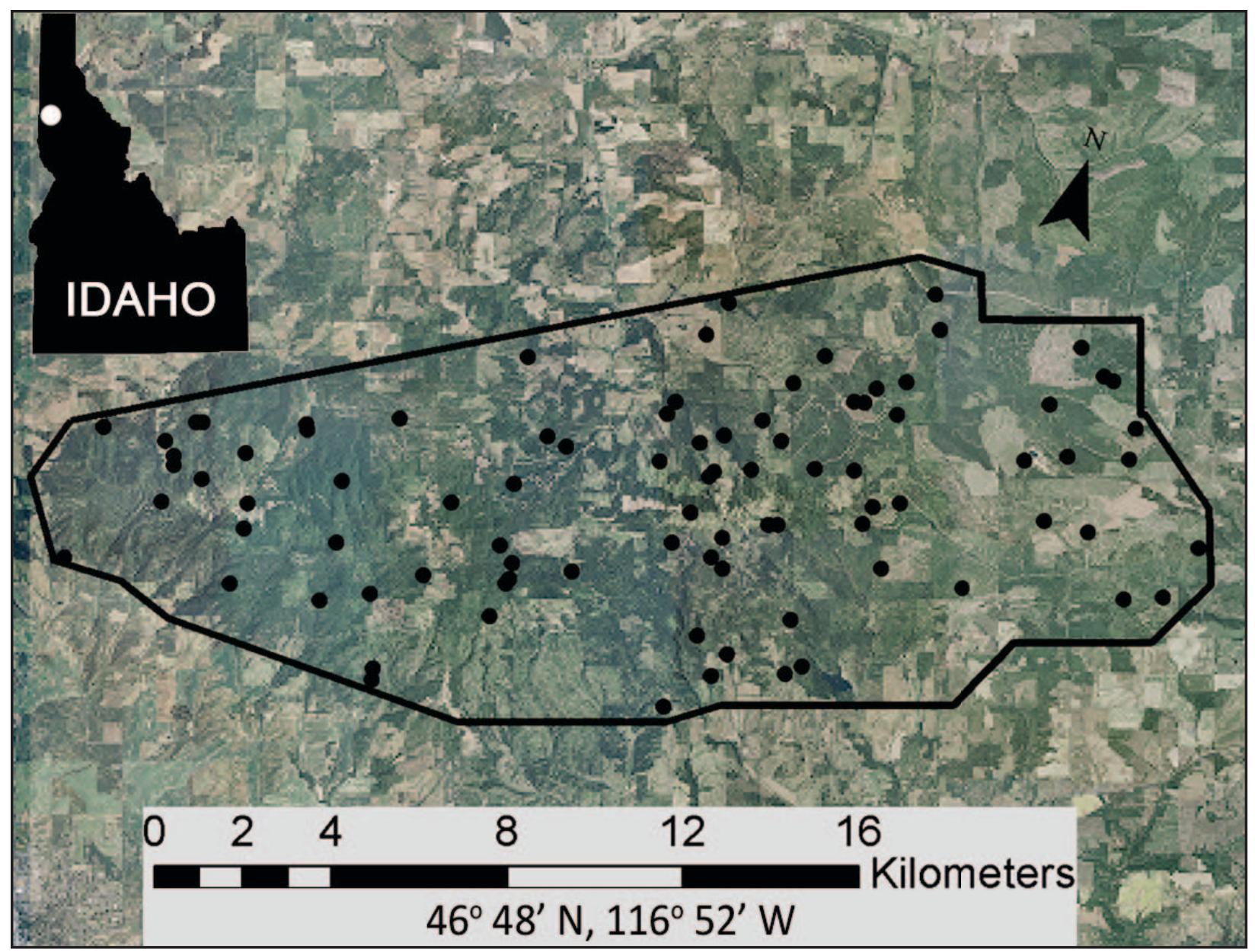

Figure 1. 2009 orthoimagery of the Moscow Mountain, Idaho, USA, study area (outlined) from the United States Geological Survey. The white dot in the inset is the study area. Plot locations are indicated with black dots.

agement practices including thinning, timber harvesting, and prescribed burning (Hudak et al. 2012). These activities have resulted in a forest with varying stand ages and structures that occur over a variety of biophysical settings (Falkowski et al. 2009, Martinuzzi et al. 2009, Hudak et al. 2012).

\section{Plot Fuel Loadings}

Plot data used in this study were collected in 2009, with information on plot placement and methodologies described in detail in $\mathrm{Hu}-$ dak et al. (2012). Following a stratified random sampling design of the study area, 0.04 ha fixed-radius field plots were placed ran- domly within strata based on elevation, slope, aspect, and percent forest cover. Plots that randomly fell within agricultural areas were subsequently excluded, leaving 87 forested plots for this analysis. Within each plot, duff; litter; coarse woody debris (CWD) in the $\geq 1000$ hour $(\geq 7.62 \mathrm{~cm})$ size class; and fine woody debris in one hour $(<0.635 \mathrm{~cm})$, ten hour $(0.635 \mathrm{~cm}$ to $2.54 \mathrm{~cm})$, and 100 hour $(2.54 \mathrm{~cm}$ to $7.62 \mathrm{~cm})$ size classes were measured and loading was determined as described by Hudak et al. (2009), briefly summarized as follows: fuel loading was determined using two parallel $15 \mathrm{~m}$ Brown's transects (Brown 1974) centered $2.5 \mathrm{~m}$ upslope and downslope from plot center. On each transect, 
one hour and ten hour fuels were tallied over a $1.8 \mathrm{~m}$ segment, $100 \mathrm{~h}$ fuels over a $4.6 \mathrm{~m} \mathrm{seg-}$ ment, and $1000 \mathrm{~h}$ fuels over the entire length of both transects. Shrub and herbaceous cover were estimated ocularly and translated to loadings using equations from Brown (1981) and Smith and Brand (1983). Duff and litter depths were measured once at a set distance along each transect (Brown 1981), and loading was derived from relationships presented in Brown et al. (1982) with bulk densities from Woodall and Monleon (2008).

\section{LANDFIRE Fire Effects Fuel Model Loadings}

LANDFIRE FEFM map layers are available for both FCCS and FLM fuel classification systems. The FCCS system is composed of fuel loading data organized by vegetation type; each vegetation type is represented by loadings derived from field data collected from that vegetation type (Ottmar et al. 2007). FLM fuel loadings are the result of several field-collected datasets, which are grouped into statistically distinct groups based on fuel loading and modeled fire effects (i.e., emissions and soil heating; Lutes et al. 2009). Indepth comparisons of these approaches have been addressed by Keane (2013).

For this study, we compared LANDFIRE Refresh 2008 FEFMs to measured fuel loadings. LANDFIRE-FCCS and LANDFIRE-FLM layers were generated using different methodologies. LANDFIRE-FCCS layers were derived by matching FCCS fuelbeds to LANDFIRE vegetation communities (Comer et al. 2003) and vegetation type (McKenzie et al. 2012, LANDFIRE Team 2014a). LANDFIRE-FLMs were derived by a series of database queries that matched LANDFIRE data to the appropriate FLMs (Hann et al. 2012). More specifically, Forest Inventory and Analysis (FIA) data (Woudenberg et al. 2010) were keyed to FLMs (Lutes et al. 2009) and these FLMs were systematically matched to LANDFIRE vegetation types and cover. We should note that the scope of our study focuses on the surface fuel loadings represented in LANDFIRE map layers, not the FCCS and FLM fuel classification systems that the layers are intended to represent.

\section{Generating Emissions within FOFEM and Consume}

Consumption and emissions were generated using two common fire effects models: Consume version 4.2 (FERA Team 2014) and the Fire Order Fire Effects Model (FOFEM) version 6.0 (Lutes 2012). Consume calculates consumption and emissions based on empirical algorithms from many studies (Prichard et al. 2005). The FOFEM model generates consumption based on equations from the BURNUP model (Albini and Reinhardt 1997) and emission factors from Ward et al. (1993). Evaluating results in both models is important as FOFEM and Consume are both commonly used in fire management and are integrated into planning tools such as the Interagency Fuels Treatment Decision Support System (IFTDSS 2015). Consume is also integrated into the BlueSky Framework that is used for emissions calculations (AirFire 2015). For this study, we included the major compounds emitted by wildland fire that could be of concern for reasons of human health effects, regulatory impacts, or greenhouse gas emissions: carbon dioxide $\left(\mathrm{CO}_{2}\right)$, carbon monoxide $(\mathrm{CO})$, methane $\left(\mathrm{CH}_{4}\right)$, and particulate matter $2.5 \mu \mathrm{m}$ and $10 \mu \mathrm{m}\left(\mathrm{PM}_{2.5}\right.$ and $\left.\mathrm{PM}_{10}\right)$. Nitrogen oxides $\left(\mathrm{NO}_{\mathrm{x}}\right)$ and sulfur dioxide $\left(\mathrm{SO}_{2}\right)$ were also modeled using only FOFEM, and non-methane hydrocarbons (NMHC) were modeled using only Consume as these options are specific to each model. To parameterize these models we used the values in Table 1 to simulate summer fire conditions under which past fires in the region have ignited (McDonough 2003). 
Table 1. Environmental parameters used to populate FOFEM and Consume under default 'Low' moisture conditions to simulate an early summer fire.

\begin{tabular}{ll}
\hline Parameter & Input \\
\hline Moistures & \\
Duff & $40 \%$ \\
10 hour & $10 \%$ \\
CWD & $15 \%$ \\
Soil & $10 \%$ \\
Fuel type & Natural \\
\hline Region & Interior West \\
\hline Season & Summer \\
\hline
\end{tabular}

\section{Statistical Comparison of Fuel Loadings}

All analyses were conducted using R Statistical Software (R-Project 2013). We initially tested fuel loading differences using Bartlett's test for equal variance (Bartlett 1937). This indicated that the data did not meet the assumption of homoscedasticity required for parametric regression analysis. Therefore, we used non-parametric statistical methods. Analysis of variance was chosen and performed using the Anova test from the "car" package (Fox et al. 2014) as this version implemented the test using heteroscedasticity-corrected coefficient covariance matrices. If a significant difference was detected, further analysis was conducted with the Dunnett-Tukey-Kramer pairwise multiple comparison test adjusted for unequal variances and unequal sample sizes (Dunnet 1980) using the DTK package (Lau 2013) at the alpha $=0.05$ significance level. This method was used to compare fuel loadings, consumption, and emissions. To examine the influence of different fuels on the total emissions produced, we used Hoffman and Gardner's Importance Index, a ratio of variances between total emissions generated and each individual fuel component (Hoffman and Gardner 1983, Hamby 1994). Values close to one indicate higher significance than values closer to zero.

\section{RESULTS}

\section{Fuel Loadings}

In comparing LANDFIRE fuel loadings with measured fuel loadings, all fuel components differed at the alpha $=0.05$ significance level with the exception of shrubs (Table 2, Figure 2). LANDFIRE-FCCS loadings over-represented duff and herbs; under-represented litter, $10 \mathrm{~h}$, and $100 \mathrm{~h}$ fuels; and did not differ for $1 \mathrm{~h}$ fuels or CWD. LANDFIRE-FLM under-represented duff, litter, fine $(1 \mathrm{~h}, 10 \mathrm{~h}$, and $100 \mathrm{~h}$ ), and CWD fuel loadings; over-represented herb loadings; but duff loading did not

Table 2. Mean fuel loads ( $\mathrm{Mg} \mathrm{ha}^{-1}$ and SD in parentheses) on measured plots and as modeled by LANDFIRE-FCCS and LANDFIRE-FLM. Asterisks indicate statistically significant difference relative to measured loading data at the $P<0.05$ significance level.

\begin{tabular}{lccc}
\hline & \multicolumn{3}{c}{ Mean plot loading } \\
\cline { 2 - 4 } Fuel & Measured & LANDFIRE-FCCS & LANDFIRE-FLM \\
\hline Duff & $10.55(10.20)$ & $31.89(17.80)^{*}$ & $7.76(12.19)$ \\
Litter & $5.86(4.13)$ & $4.199(1.37)^{*}$ & $3.66(3.40)^{*}$ \\
$1 \mathrm{~h}$ & $0.65(0.47)$ & $0.81(0.46)$ & $0.50(0.32)^{*}$ \\
$10 \mathrm{~h}$ & $2.57(2.19)$ & $1.85(1.11)^{*}$ & $1.65(1.13)^{*}$ \\
$100 \mathrm{~h}$ & $4.98(5.20)$ & $2.47(3.41)^{*}$ & $1.94(1.66)^{*}$ \\
CWD & $20.087(23.33)$ & $18.45(16.38)$ & $2.75(4.04)^{*}$ \\
Herb & $0.46(0.28)$ & $0.68(0.76)^{*}$ & $0.73(0.76)^{*}$ \\
Shrub & $1.179(3.08)$ & $1.36(1.51)$ & $3.65(10.60)$ \\
Total fuel & $46.26(32.49)$ & $61.63(34.81)^{*}$ & $22.64(21.16)^{*}$ \\
\hline
\end{tabular}




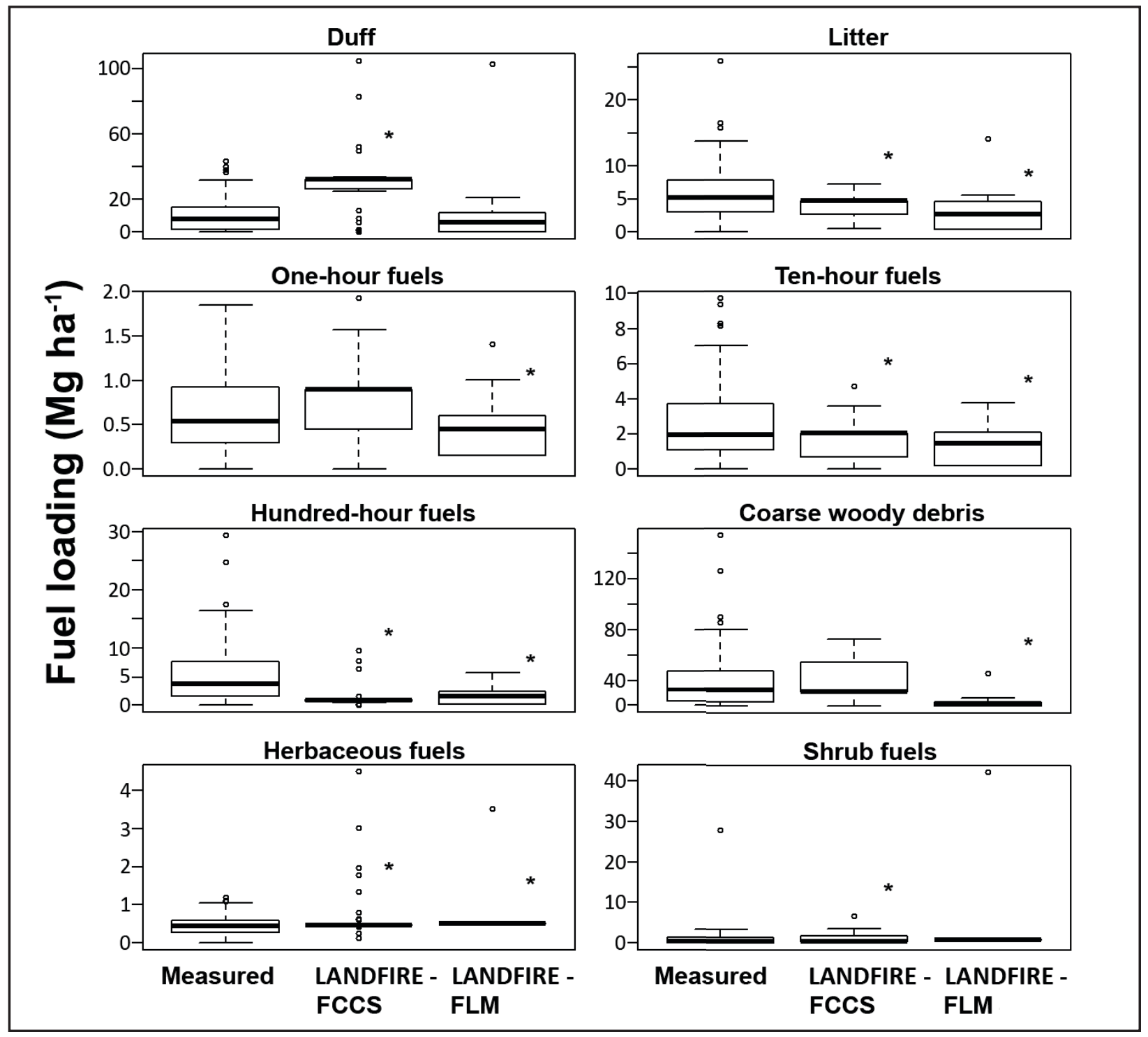

Figure 2. Differences in fuel loading for measured plots, LANDFIRE-FLM, and LANDFIRE-FCCS products. Bold horizontal lines indicate median values, asterisks represent significant differences relative to measured loadings. Circles indicate outliers, and whiskers indicate the region between the first and third quartiles.

differ. Duff and CWD fuel components showed the most pronounced difference in loadings, with LANDFIRE-FCCS duff loadings $200 \%$ higher than measured loadings, and $300 \%$ higher than LANDFIRE-FLM loadings. LANDFIRE-FLM CWD loading was 9 times lower than measured or LANDFIRE-FCCS loadings. When comparing LANDFIRE FEFMs to each other, only duff, CWD, and $1 \mathrm{~h}$ fuel loadings differed, with LANDFIRE-FCCS having the greater loadings.

\section{Modeled Consumption and Emissions in FOFEM}

The statistical relationships for fuel consumption mirrored those for fuel loading (Figures 2 and 3, Tables 2 and 3). Relative to measured consumption, the mean total surface consumption from LANDFIRE-FCCS was $23 \%$ higher, and LANDFIRE-FLM was $51 \%$ lower. It is apparent that the high LANDFIRE-FCCS duff loading led to the higher 


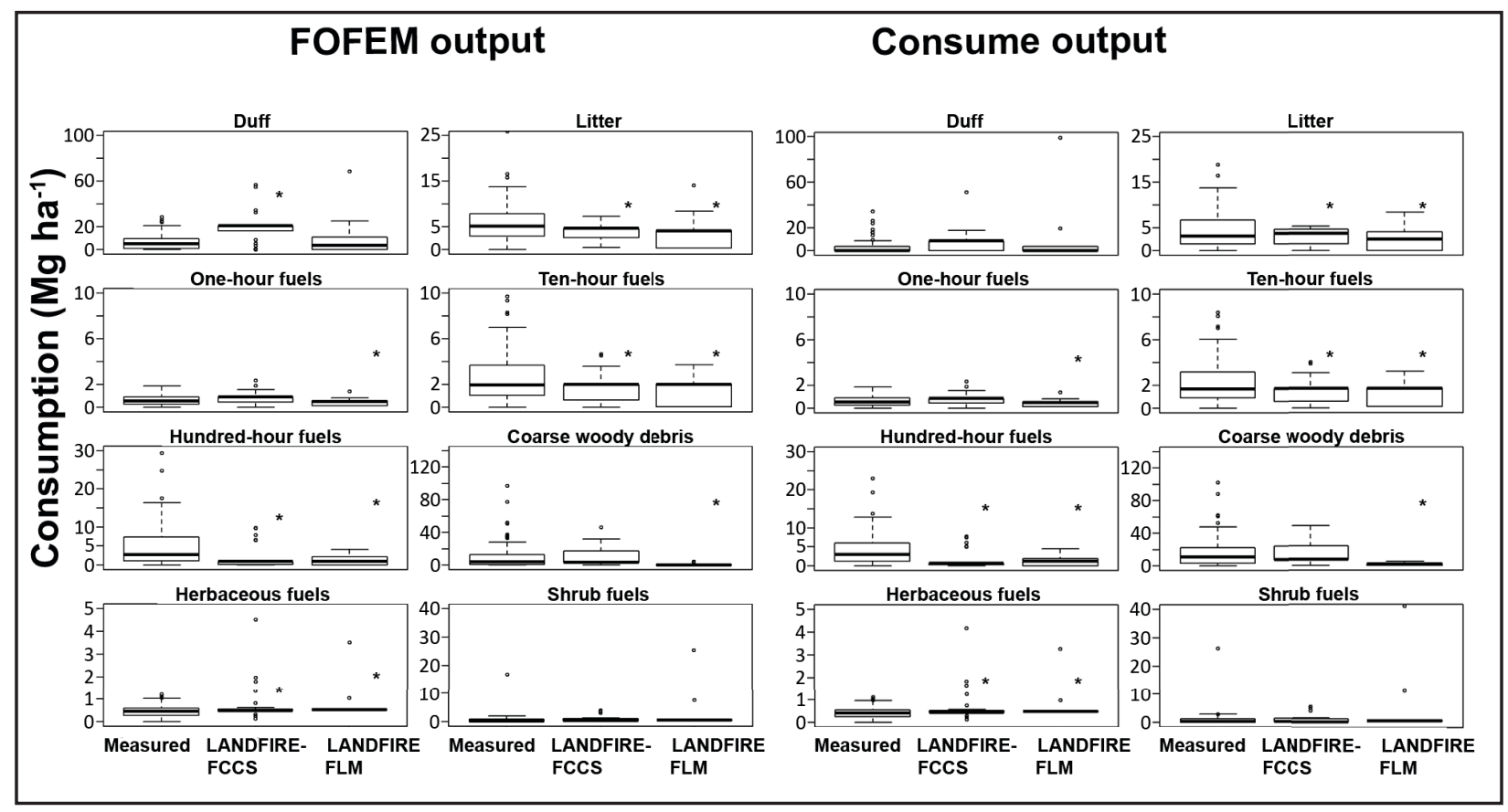

Figure 3. Differences in modeled consumption for measured, LANDFIRE-FLM, and LANDFIRE-FCCS fuel loadings. Bold horizontal lines indicate median values, asterisks represent significant differences relative to results derived from measured loadings.

Table 3. Mean fuel consumption ( $\mathrm{Mg} \mathrm{ha}^{-1}$ with $\mathrm{SD}$ in parentheses) under fixed environmental conditions or measured plots, and as modeled by LANDFIRE-FCCS and LANDFIRE-FLM, using FOFEM and Consume. Asterisks indicate statistically significant difference relative to estimates based on measured loading at the $P<0.05$ significance level.

\begin{tabular}{|c|c|c|c|c|c|c|}
\hline \multirow[b]{2}{*}{ Fuel } & \multicolumn{3}{|c|}{ Mean plot consumption in FOFEM } & \multicolumn{3}{|c|}{ Mean plot consumption in Consume } \\
\hline & Measured & $\begin{array}{l}\text { LANDFIRE- } \\
\text { FCCS }\end{array}$ & $\begin{array}{l}\text { LANDFIRE- } \\
\text { FLM }\end{array}$ & Measured & $\begin{array}{l}\text { LANDFIRE- } \\
\text { FCCS }\end{array}$ & $\begin{array}{l}\text { LANDFIRE- } \\
\text { FLM }\end{array}$ \\
\hline Duff & $6.98(6.84)$ & $20.64(11.66)^{*}$ & $5.35(8.38)$ & $3.36(6.48)$ & $5.67(8.48)$ & $2.31(10.83)$ \\
\hline Litter & $5.83(4.16)$ & $4.14(1.21)^{*}$ & $3.68(3.23)^{*}$ & $4.45(3.98)$ & $3.11(1.66)^{*}$ & $2.32(1.71)^{*}$ \\
\hline $1 \mathrm{~h}$ & $0.65(0.49)$ & $0.76(0.44)$ & 0.49 (0.29)* & $0.65(0.49)$ & $0.75(0.44)$ & $0.49(0.29)^{*}$ \\
\hline $10 \mathrm{~h}$ & $2.58(2.19)$ & $1.77(1.17)^{*}$ & $1.62(1.19)^{*}$ & $2.24(1.89)$ & $1.53(1.00)^{*}$ & $1.44(0.98)^{*}$ \\
\hline $100 \mathrm{~h}$ & $4.56(5.29)$ & $2.32(3.46)^{*}$ & $1.47(1.25)^{*}$ & $3.93(4.06)$ & $1.84(2.70)^{*}$ & $1.55(1.30)^{*}$ \\
\hline CWD & $10.59(16.88)$ & $8.60(10.84)$ & $0.53(0.67)^{*}$ & $17.06(19.41)$ & $14.20(14.17)$ & $1.84(1.56)^{*}$ \\
\hline Herb & $0.45(0.28)$ & $0.66(0.61)^{*}$ & $0.70(0.70)^{*}$ & $0.42(0.26)$ & $0.61(0.57)^{*}$ & $0.64(0.65)^{*}$ \\
\hline Shrub & $0.70(1.85)$ & $0.99(1.20)$ & $1.99(5.87)$ & $1.02(2.88)$ & $1.41(1.74)$ & $3.10(9.48)$ \\
\hline Total fuel & $32.35(25.46)$ & $39.89(23.40)$ & $15.83(14.30)$ & $33.12(25.90)$ & $29.13(18.61)$ & $13.69(16.08)^{*}$ \\
\hline
\end{tabular}

overall consumption, and that the low CWD loading in the LANDFIRE-FLM contributed to less consumption. This in turn had a direct effect on the emissions modeled. All modeled emissions, with the exception of $\mathrm{NO}_{\mathrm{x}}$, were significantly higher when modeled using LANDFIRE-FCCS loadings, and lower when using LANDFIRE-FLM loadings, while emissions derived from measured fuel loadings fell in between (Table 4, Figure 4).

The relative importance of CWD and duff to total emissions was reaffirmed and quantified using the importance index (Table 5). Duff and CWD stood out as the primary con- 
Table 4. Mean modeled emissions ( $\mathrm{Mg} \mathrm{ha}^{-1}$ with SD in parentheses) calculated using FOFEM and Consume for measured plots, LANDFIRE-FCCS, and LANDFIRE-FLM. Asterisks indicate statistically significant difference relative to estimates based on measured loading at the $P<0.05$ significance level.

\begin{tabular}{|c|c|c|c|c|c|c|}
\hline \multirow[b]{2}{*}{ Effect } & \multicolumn{3}{|c|}{ Plot-level values FOFEM } & \multicolumn{3}{|c|}{ Plot-level values Consume } \\
\hline & Measured & $\begin{array}{l}\text { LANDFIRE- } \\
\text { FCCS }\end{array}$ & $\begin{array}{c}\text { LANDFIRE- } \\
\text { FLM }\end{array}$ & Measured & $\begin{array}{l}\text { LANDFIRE- } \\
\text { FCCS }\end{array}$ & $\begin{array}{c}\text { LANDFIRE- } \\
\text { FLM }\end{array}$ \\
\hline $\mathrm{CH}_{4}$ & $0.32(0.30)$ & $0.46(0.30)^{*}$ & $0.13(0.14)^{*}$ & $0.19(0.18)$ & $0.19(0.14)$ & $0.06(0.11)^{*}$ \\
\hline $\mathrm{CO}$ & $6.83(6.56)$ & $10.00(6.64)^{*}$ & $2.67(3.00)^{*}$ & $3.67(3.38)$ & $3.65(2.65)$ & $1.20(2.02)^{*}$ \\
\hline $\mathrm{CO}_{2}$ & $45.20(34.09)$ & $52.81(29.57)$ & $23.39(21.90)^{*}$ & $51.90(39.72)$ & $44.82(28.11)$ & $22.08(25.22)^{*}$ \\
\hline $\mathrm{PM}_{2.5}$ & $0.53(0.50)$ & $0.76(0.50)^{*}$ & $0.22(0.23)^{*}$ & $0.29(0.25)$ & $0.27(0.19)$ & $0.11(0.15)^{*}$ \\
\hline $\mathrm{PM}_{10}$ & $0.63(0.59)$ & $0.90(0.59)^{*}$ & $0.25(0.27)^{*}$ & $0.33(0.28)$ & $0.30(0.21)$ & $0.12(0.16)^{*}$ \\
\hline $\mathrm{SO}_{2}$ & $0.03(0.03)$ & $0.04(0.02)$ & $0.02(0.01)^{*}$ & & & \\
\hline $\mathrm{NO}_{\mathrm{x}}$ & $0.03(0.03)$ & $0.02(0.01)^{*}$ & $0.02(0.03)$ & & & \\
\hline NMHC & & & & $0.16(0.14)$ & $0.15(0.11)$ & $0.05(0.08)^{*}$ \\
\hline
\end{tabular}

tributors to total emissions in all cases, with the exception of LANDFIRE-FLM data, in which duff and shrub loadings were the primary contributors. Although shrub loadings did not statistically different in our study, shrub loadings tended to be higher in LANDFIRE-FLMs compared to other sources.

\section{Modeled Consumption and Emissions in Consume}

With the exception of duff, the relationships between fuel loading and modeled consumption when using Consume remained the same as with FOFEM; modeled duff consumption was much lower when using Consume (Table 3). Duff consumption using LANDFIRE-FCCS loadings did not significantly differ from consumption generated from measured loadings. Because of this, the overall modeled fuel consumption from LANDFIRE-FCCS did not significantly differ from the fuel consumption generated by measured loadings. However, the modeled consumption from LANDFIRE-FLM was significantly lower than consumption from measured loadings, with mean total surface fuel consumption $59 \%$ less than that derived from measured fuel loadings.

The importance index for the consumption and total emissions in Consume was similar to the FOFEM emissions importance index (Table 5). Duff consumption was still an important component with regard to emissions production, even though it did not statistically differ between measured and modeled fuel datasets when modeled with Consume. When emissions were evaluated, the LANDFIRE-FLM generated emissions were significantly lower than those generated using measured fuel loadings. Emissions generated using LANDFIRE-FCCS and measured fuel loadings did not differ from each other (Table 4).

\section{DISCUSSION}

\section{Measured Versus Modeled Fuel Loading}

Duff and CWD led to the most significant differences in modeled consumption and emissions. LANDFIRE-FLMs contained higher shrub loadings, although this number did not result in a statistically significant difference, nor was it great enough to influence the total surface fuel loading when consumption and emissions were modeled. While the cause for these LANDFIRE-FLM shrub values to be so much higher is not known, the FLM system itself was developed with very little available shrub data (Lutes et al. 2009). This likely influenced which FLMs were available to assign 


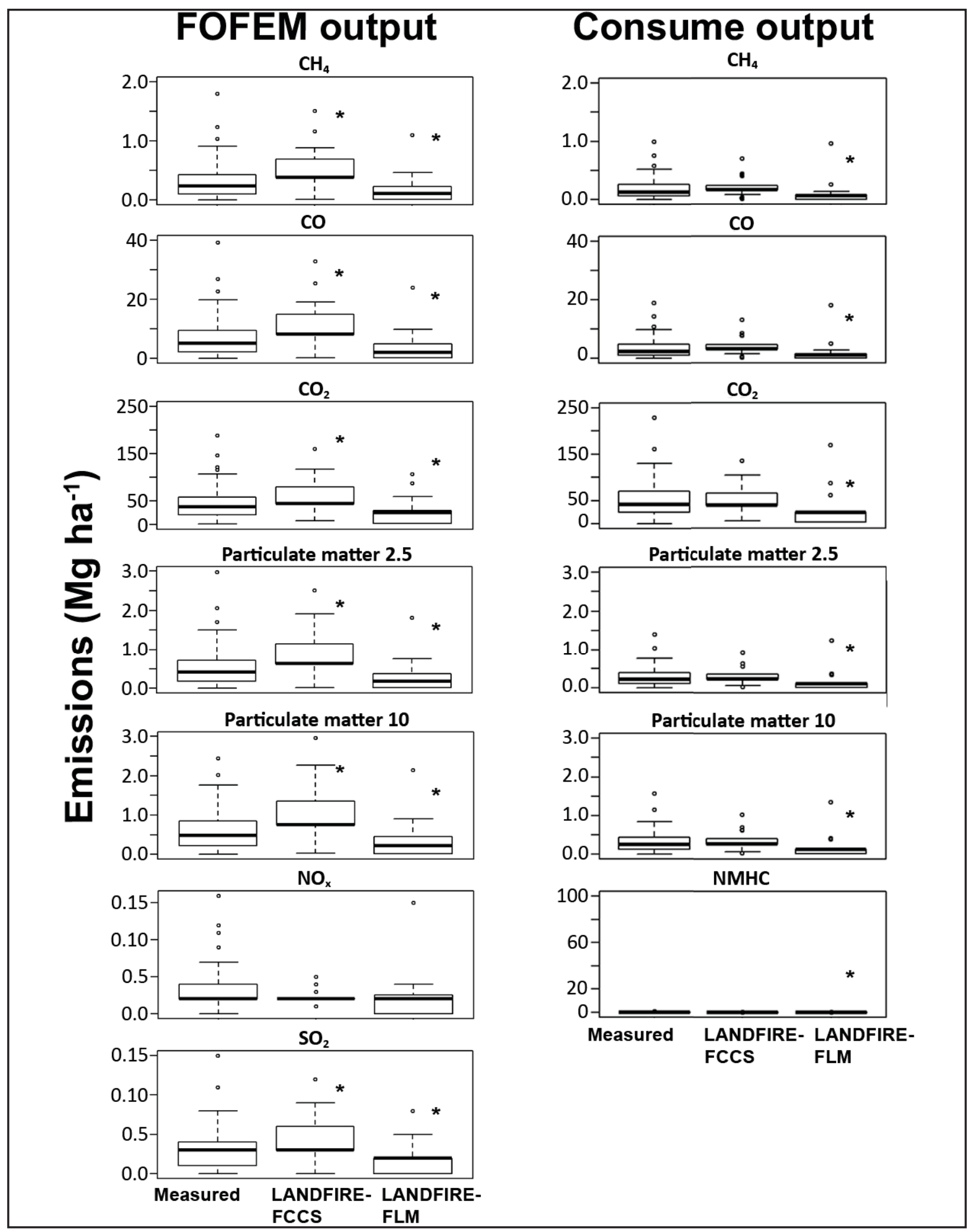

Figure 4. Differences in modeled emissions for measured, LANDFIRE-FLM, and LANDFIRE-FCCS fuel loadings. Bold horizontal lines indicate median values, asterisks represent significant differences relative to results derived from measured loadings. 
Table 5. Hoffman and Gardner Importance Index for each FEFM and each fuel type shows that the fuel of relative importance to the total emissions produced varied depending by FEFM. Emissions from measured data and FCCS fuelbeds were most influenced by CWD and duff, and FLM by duff and shrubs, respectively. Highest values are indicated in bold.

\begin{tabular}{|c|c|c|c|c|c|c|}
\hline \multirow[b]{2}{*}{ Fuel } & \multicolumn{3}{|c|}{ Importance Index FOFEM } & \multicolumn{3}{|c|}{ Importance Index Consume } \\
\hline & Measured & $\begin{array}{l}\text { LANDFIRE- } \\
\text { FCCS }\end{array}$ & $\begin{array}{l}\text { LANDFIRE- } \\
\text { FLM }\end{array}$ & Measured & $\begin{array}{l}\text { LANDFIRE- } \\
\text { FCCS }\end{array}$ & $\begin{array}{l}\text { LANDFIRE- } \\
\text { FLM }\end{array}$ \\
\hline$\overline{\text { Duff }}$ & 0.012 & 0.043 & 0.053 & 0.022 & 0.073 & 0.0156 \\
\hline Litter & 0.002 & 0.000 & 0.004 & 0.008 & 0.003 & 0.004 \\
\hline $1 \mathrm{~h}$ & $<0.001$ & $<0.001$ & $<0.001$ & $<0.001$ & $<0.001$ & $<0.001$ \\
\hline $10 \mathrm{~h}$ & 0.001 & $<0.001$ & $<0.001$ & 0.002 & 0.001 & 0.001 \\
\hline $100 \mathrm{~h}$ & 0.003 & 0.002 & 0.001 & 0.009 & 0.007 & 0.002 \\
\hline CWD & 0.063 & 0.048 & 0.001 & 0.196 & 0.204 & 0.003 \\
\hline Herb & $<0.001$ & $<0.001$ & $<0.001$ & $<0.001$ & $<0.001$ & 0.001 \\
\hline Shrub & 0.001 & 0.001 & 0.032 & 0.004 & 0.003 & 0.119 \\
\hline
\end{tabular}

to LANDFIRE maps when the LANDFIRE-FLM was created. Because the scope of this study focused on a mixed conifer ecosystem, our shrub data were somewhat limited and probably provided little insight in shrub-dominated ecosystems where shrubs are a large fuel component. Further investigation of these LANDFIRE layers in shrub-dominated systems and further fuel loading data from shrub ecosystems would be beneficial to further refining FLMs and the resulting LANDFIRE-FLM data for shrub ecosystems.

When comparing each fuel component for measured and LANDFIRE-represented loadings with those of other mixed conifer systems, all three of our fuel loading sets fell within the ranges observed by other researchers (Table 6). Focusing on duff and coarse woody debris, we found LANDFIRE-FCCS mean duff loading exceeded our measured values, but more closely resembled the ranges found in other mixed conifer forests. Thus, it is possible that our study area may have had less duff loading than other mixed conifer forests. When evaluating mean CWD loadings, we found the wide range noted in other studies, from $0.5 \mathrm{Mg} \mathrm{ha}^{-1}$ to $37 \mathrm{Mg} \mathrm{ha}^{-1}$; LANDFIRE-FLM mean CWD loadings were at the low end of this range averaging $0.53 \mathrm{Mg} \mathrm{ha}^{-1}$, while our measured data and LAND-
FIRE-FCCS were 10.6 $\mathrm{Mg} \mathrm{ha}^{-1}$ and $8.6 \mathrm{Mg}$ $\mathrm{ha}^{-1}$, respectively.

Our results support a broader evaluation of the importance of various steps in the emissions modeling process in which Drury et al. (2014) compared LANDFIRE-represented loadings to a custom loading map based on measured data. Like our results, their duff loading was higher for LANDFIRE-FCCS relative to loadings represented using measured data, while in our study the LANDFIRE-FCCS total loadings were greater. Drury et al. found a wide range in possible fuel loadings depending upon the method chosen, as did we, and concluded that custom fuel loading layers derived from measured data produced the most reliable emissions estimates. Of the two LANDFIRE fuel layers, Drury et al. found the LANDFIRE-FCCS layer produced results closer to the custom loading layers. We found this to be true in our study when modeling emissions with Consume, but still found LANDFIRE-FCCS to produce higher emissions values when modeled using FOFEM.

In another study that compared classification, mapping accuracy, and fuel loadings of LANDFIRE-FCCS and LANDFIRE-FLM to Forest Inventory and Analysis (FIA) plot data across the western US, Keane et al. (2013) found poor performance in both LAND- 
Table 6. Fuel loading for other mixed conifer forests in the western United States compared with mean fuel loading from this study (in $\mathrm{Mg} \mathrm{ha}^{-1}$ ). Standard deviations, when present, are indicated in parentheses. Values from this study are indicated in bold in the last three rows.

\begin{tabular}{|c|c|c|c|c|c|c|c|c|c|c|}
\hline Source & Duff & Litter & $\begin{array}{c}1 \\
\text { hour }\end{array}$ & $\begin{array}{c}10 \\
\text { hour }\end{array}$ & $\begin{array}{c}100 \\
\text { hour }\end{array}$ & $\begin{array}{l}1000 \mathrm{~h} \\
\text { sound }\end{array}$ & $\begin{array}{l}1000 \mathrm{~h} \\
\text { rotten }\end{array}$ & Herb & Location & $\begin{array}{c}\text { Elevation } \\
(\mathrm{m})\end{array}$ \\
\hline $\begin{array}{l}\text { Hille and } \\
\text { Stephens } \\
2005\end{array}$ & $\begin{array}{l}17.8 \\
(3.6)\end{array}$ & $\begin{array}{l}17.8 \\
(3.6)\end{array}$ & $\begin{array}{c}2.0 \\
(0.2)\end{array}$ & $\begin{array}{c}6.3 \\
(0.7)\end{array}$ & $\begin{array}{c}5.8 \\
(1.6)\end{array}$ & $\begin{array}{c}6.0 \\
(3.3)\end{array}$ & $\begin{array}{l}15.8 \\
(4.3)\end{array}$ & - & $\begin{array}{l}\text { North-central Sierra } \\
\text { Nevada, California }\end{array}$ & $\begin{array}{l}1200 \text { to } \\
1500\end{array}$ \\
\hline $\begin{array}{l}\text { Sikkink and } \\
\text { Keane } 2008\end{array}$ & & & 0.019 & 1.649 & 0.513 & $\begin{array}{l}0.683 \\
\text { and } \mathrm{r}\end{array}$ & $\begin{array}{l}\text { (sound } \\
\text { otten) }\end{array}$ & 0.545 & NW Rockies* & $\begin{array}{l}730 \text { to } \\
2130\end{array}$ \\
\hline $\begin{array}{l}\text { Sikkink and } \\
\text { Keane } 2008\end{array}$ & & & 0.012 & 1.297 & 0.671 & $\begin{array}{l}0.549 \\
\text { and } \mathrm{r}\end{array}$ & $\begin{array}{l}\text { (sound } \\
\text { otten) }\end{array}$ & 0.659 & NW Rockies & $\begin{array}{l}730 \text { to } \\
2130\end{array}$ \\
\hline $\begin{array}{l}\text { Sikkink and } \\
\text { Keane } 2008\end{array}$ & & & 0.107 & 0.709 & 1.105 & $\begin{array}{l}0.937 \\
\text { and } \mathrm{r}\end{array}$ & $\begin{array}{l}\text { (sound } \\
\text { otten) }\end{array}$ & 0.581 & NW Rockies & \\
\hline $\begin{array}{l}\text { Sikkink and } \\
\text { Keane } 2008\end{array}$ & & & 1.155 & 4.390 & 5.682 & $\begin{array}{l}0.600 \\
\text { and } \mathrm{r}\end{array}$ & $\begin{array}{l}\text { (sound } \\
\text { otten) }\end{array}$ & 0.615 & NW Rockies & $\begin{array}{l}730 \text { to } \\
2130\end{array}$ \\
\hline $\begin{array}{l}\text { Sikkink and } \\
\text { Keane } 2008\end{array}$ & & & 2.586 & 5.567 & 7.849 & $\begin{array}{l}0.863 \\
\text { and } \mathrm{r}\end{array}$ & $\begin{array}{l}\text { (sound } \\
\text { otten) }\end{array}$ & 0.636 & NW Rockies & $\begin{array}{l}730 \text { to } \\
2130\end{array}$ \\
\hline $\begin{array}{l}\text { Youngblood } \\
\text { et al. } 2008\end{array}$ & $\begin{array}{l}22.27 \\
(7.52)\end{array}$ & $\begin{array}{c}5.9 \\
(0.97)\end{array}$ & $\begin{array}{l}0.94 \\
(0.2)\end{array}$ & $\begin{array}{l}1.56 \\
(0.33)\end{array}$ & $\begin{array}{c}4.16 \\
(0.59)\end{array}$ & $\begin{array}{c}9.63 \\
(3.46)\end{array}$ & $\begin{array}{l}7.31 \\
(2.5)\end{array}$ & & $\begin{array}{l}\text { Blue Mountain } \\
\text { Region, Oregon }\end{array}$ & $\begin{array}{c}1040 \text { to } \\
1480\end{array}$ \\
\hline $\begin{array}{l}\text { Youngblood } \\
\text { et al. } 2008\end{array}$ & $\begin{array}{l}25.48 \\
(7.03)\end{array}$ & $\begin{array}{c}3.74 \\
(0.44)\end{array}$ & $\begin{array}{c}0.37 \\
(0.12)\end{array}$ & $\begin{array}{c}0.64 \\
(0.21)\end{array}$ & $\begin{array}{c}3.04 \\
(0.67)\end{array}$ & $\begin{array}{c}8.88 \\
(4.26)\end{array}$ & $\begin{array}{c}7.97 \\
(0.61)\end{array}$ & & $\begin{array}{l}\text { Blue } \\
\text { Regi }\end{array}$ & $\begin{array}{l}1040 \text { to } \\
1480\end{array}$ \\
\hline $\begin{array}{l}\text { Raymond } \\
\text { and Peterson } \\
2005\end{array}$ & & & 1.2 & 4.1 & 4.8 & & & 1.2 & Oregon Coast Range & $\begin{array}{l}670 \text { to } \\
850\end{array}$ \\
\hline $\begin{array}{l}\text { Raymond } \\
\text { and Peterson } \\
2005\end{array}$ & & & 4.4 & 6.8 & 8.7 & & & 1.2 & Oregon Coast Range & $\begin{array}{l}670 \text { to } \\
850\end{array}$ \\
\hline $\begin{array}{l}\text { Kobziar et } \\
\text { al. } 2006\end{array}$ & & & $\begin{array}{l}1.25 \\
(0.87)\end{array}$ & $\begin{array}{c}4.53 \\
(3.23)\end{array}$ & $\begin{array}{c}9.93 \\
(8.18)\end{array}$ & $\begin{array}{c}7.52 \\
(16.82)\end{array}$ & $\begin{array}{l}14.18 \\
(23.31)\end{array}$ & & $\begin{array}{l}\text { North-central Sierra } \\
\text { Nevada, California }\end{array}$ & $\begin{array}{c}1100 \text { to } \\
1410\end{array}$ \\
\hline $\begin{array}{l}\text { Kobziar et } \\
\text { al. } 2006\end{array}$ & & & $\begin{array}{l}1.13 \\
(1.04)\end{array}$ & $\begin{array}{c}5.53 \\
(4.97)\end{array}$ & $\begin{array}{c}6.17 \\
(7.15)\end{array}$ & $\begin{array}{c}7.91 \\
(17.04)\end{array}$ & $\begin{array}{l}29.02 \\
(40.86)\end{array}$ & & $\begin{array}{l}\text { North-central Sierra } \\
\text { Nevada, California }\end{array}$ & $\begin{array}{l}1100 \text { to } \\
1410\end{array}$ \\
\hline $\begin{array}{l}\text { Kobziar et } \\
\text { al. } 2006\end{array}$ & & & $\begin{array}{c}0.9 \\
(0.71)\end{array}$ & $\begin{array}{c}2.9 \\
(2.3)\end{array}$ & $\begin{array}{c}4.25 \\
(4.12)\end{array}$ & $\begin{array}{c}2.57 \\
(5.36)\end{array}$ & $\begin{array}{c}26.62 \\
(65.62)\end{array}$ & & $\begin{array}{l}\text { North-central Sierra } \\
\text { Nevada, California }\end{array}$ & $\begin{array}{l}1100 \text { to } \\
1410\end{array}$ \\
\hline $\begin{array}{l}\text { Reinhard et } \\
\text { al.1991 }\end{array}$ & $\begin{array}{c}52 \\
(1.3)\end{array}$ & & & Other $\mathrm{v}_{1}$ & $\begin{array}{l}\text { alues ar } \\
\text { not natu }\end{array}$ & $\begin{array}{l}\text { re loggin } \\
\text { ural fuels }\end{array}$ & g slash, & & NW Rockies & $\begin{array}{l}900 \text { to } \\
1200\end{array}$ \\
\hline $\begin{array}{l}\text { Reinhard et } \\
\text { al. } 1991\end{array}$ & $\begin{array}{l}48.4 \\
(1.6) \\
\end{array}$ & & & $\begin{array}{r}\text { Other } \mathrm{v} \\
1\end{array}$ & $\begin{array}{l}\text { alues ar } \\
\text { not natu }\end{array}$ & re loggin & g slash, & & NW Rockies & $\begin{array}{c}900 \text { to } \\
1200 \\
\end{array}$ \\
\hline Measured & $\begin{array}{c}10.55 \\
(10.20)\end{array}$ & $\begin{array}{c}5.86 \\
(4.13)\end{array}$ & $\begin{array}{c}0.65 \\
(0.47)\end{array}$ & $\begin{array}{c}2.57 \\
(2.19)\end{array}$ & $\begin{array}{c}4.98 \\
(5.20)\end{array}$ & $\begin{array}{r}\mathbf{2 0 . 0 9} \\
\text { (soun } \\
\text { rott }\end{array}$ & $\begin{array}{l}\text { (23.33) } \\
\text { id and } \\
\text { ten) }\end{array}$ & $\begin{array}{c}0.46 \\
(0.28)\end{array}$ & NW Rockies & $\begin{array}{c}770 \text { to } \\
1516\end{array}$ \\
\hline $\begin{array}{l}\text { LANDFIRE- } \\
\text { FLM }\end{array}$ & $\begin{array}{c}7.76 \\
(12.19)\end{array}$ & $\begin{array}{r}3.66 \\
(3.40)\end{array}$ & $\begin{array}{c}0.50 \\
(\mathbf{0 . 3 2})\end{array}$ & $\begin{array}{c}1.65 \\
(1.13)\end{array}$ & $\begin{array}{c}2.47 \\
(3.41)\end{array}$ & $\begin{array}{l}2.75 \\
\text { (soun } \\
\text { rott }\end{array}$ & $\begin{array}{l}(4.04) \\
\text { ld and } \\
\text { ten) }\end{array}$ & $\begin{array}{r}0.73 \\
(0.76)\end{array}$ & NW Rockies & $\begin{array}{l}770 \text { to } \\
1516\end{array}$ \\
\hline $\begin{array}{l}\text { LANDFIRE- } \\
\text { FCCS }\end{array}$ & $\begin{array}{l}31.89 \\
(17.8)\end{array}$ & $\begin{array}{c}4.19 \\
(1.37)\end{array}$ & $\begin{array}{c}0.81 \\
(0.46)\end{array}$ & $\begin{array}{c}1.85 \\
(1.11)\end{array}$ & $\begin{array}{c}1.94 \\
(1.66)\end{array}$ & $\begin{array}{r}18.45 \\
\text { (soun } \\
\text { rott }\end{array}$ & $\begin{array}{l}(16.38) \\
\text { de and } \\
\text { ten) }\end{array}$ & $\begin{array}{c}0.68 \\
(0.76)\end{array}$ & NW Rockies & $\begin{array}{l}770 \text { to } \\
1516\end{array}$ \\
\hline
\end{tabular}

* NW Rockies includes parts of Idaho and Montana, USA. 
FIRE-represented FEFMs. LANDFIRE-FLM tended to under-predict loadings while LANDFIRE-FCCS tended toward over prediction. However, LANDFIRE-FLM loadings had lower root mean squared errors (Keane et al. 2013). Our findings here support the work of Keane et al. (2013) and Drury et al. (2014) in describing the tendency of LANDFIRE-FCCS to have higher loadings relative to LANDFIRE-FLMs.

\section{Modeled Consumption and Emissions Using FOFEM}

Relative differences in consumption values when modeled with FOFEM mirrored those of the loading values. High LANDFIRE-FCCS duff and low LANDFIRE-FLM CWD loading and consumption contributed to the total modeled emissions being highest when using LANDFIRE-FCCS inputs, and lowest when using LANDFIRE-FLM inputs. In examining the fuel loading data (Table 2), there is high variance in all fuel loading categories. This supports the work by Keane et al. (2013), who noted the high variance inherent in all categories of fuel loading, and the difficulties caused by spatial variation when trying to represent fuel loadings across large landscapes. Consumption followed the pattern of the total fuel loading values for the landscape, with LANDFIRE-FCCS being the highest, FLM being the lowest, and measured values in the middle. This in turn produced higher emissions from LANDFIRE-FCCS and lower emissions from LANDFIRE-FLM, highlighting the differences in emissions outcomes depending upon the choices made to represent fuel loadings.

\section{Modeled Consumption and Emissions Using Consume}

In comparing consumption and emissions from Consume, the choice of model has an effect on emissions generated. In this study, there were similar trends in modeled consump- tion with both fire effects models, but the lower duff consumption in Consume, relative to FOFEM, led to emissions outputs in which LANDFIRE-FCCS derived emissions did not differ from those derived from measured loadings. This difference in duff consumption is due to the fact that Consume and FOFEM calculate the consumption of duff using different equations, derived from different data sets (Reinhardt 2003, Prichard et al. 2005).

\section{Research Implications}

In modeling emissions, fuel loadings have been identified as the most crucial variables (Drury et al. 2014), yet they represent one of the greatest uncertainties in modeling emissions (French et al. 2011). In a detailed discussion on the topic, Keane et al. (2013) identified several factors creating difficulties in quantifying fuel loadings. These include lack of data to develop thorough loading maps; the use of classification systems that were developed from discrete plot locations but then applied to large, national-scale areas; and the inherent difficulty of classifying fuels into categories such as hourly size classes and duff, when each of these size classes may have different degrees of variation at different spatial scales (Keane et al. 2012, 2013). If existing fuel loading classification maps are to be improved, more data are necessary. The results of our study indicate that data on CWD and duff should be priorities, due to the relative importance of these fuels to overall emissions in mixed conifer forests (Table 5). While consumption didn't statistically differ for the specific case of shrubs, shrub loading accounted for a great deal of variability in emissions from LANDFIRE-FLMs (Table 5), a classification that was developed with little available shrub data (Lutes et al. 2009). For the case of LANDFIRE-FLMs, having additional data on shrub loadings would be beneficial.

Despite being represented at a $30 \mathrm{~m}$ resolution, LANDFIRE data layers are intended to 
be used at larger, sub-regional to national scales (LANDFIRE Team 2014b). Data from fuel loading maps may work for finer scales; however, there will likely be greater need to supplement that data with local knowledge. Based on our findings in a 20000 ha area, using measured data, especially for duff and CWD loadings, is preferable relative to unaltered LANDFIRE layers. However, we understand that measured data are often unavailable, may be incomplete, or limited in availability.

\section{Management Implications}

If monitoring resources are available, emission estimates will be improved by having more information on duff loading, as differences in duff loading lead to the greatest differences in emissions, followed by CWD. For coarse woody debris, the planar intercept sampling methods have been most commonly used in forests such as in this study, although the Photoload (Keane and Dickinson 2007 ) method has also performed well (Sikkink and Keane 2008). Duff sampling is often performed via sampling points along a planar intercept to gather both loading and depth (Brown 1974). The fuel photoseries guides available for many ecosystems provide estimates of duff loading (Ottmar et al. 2003), but there are few studies comparing their performance relative to the traditional method. If measured data are not available, one could model with both the LANDFIRE-FLM and LANDFIRE-FCCS derived fuel loadings, and then average the two sets of results.

The use of systems such as the Wildland Fire Decision Support System (WFDSS) and the Interagency Fuels Treatment Decision
Support System (IFTDSS) also hold potential for obtaining measured fuel loading information (IFTDSS 2015, WFDSS 2015). These systems provide online access to several models to represent fire behavior and effects (including emissions), but they also provide an easy platform from which data can be shared from user to user. In the future, it would be ideal to see a searchable database of user-provided fuel loadings within these decision support systems, similar to the searchable data available through the Fire Research and Management Exchange System (FRAMES) Resource Catalog (FRAMES 2015).

This study has characterized the potential differences in LANDFIRE-represented fuel loadings in a mixed conifer case study area, and their impact on the emissions modeling. While using measured data provides the most reliable outcome, either by itself or to help supplement the LANDFIRE data, this is not always possible. Web-based systems can aid in finding and sharing data; however, a search for the keywords "duff" and "coarse woody debris" in FRAMES returned 34 and 3 results, respectively. While online systems can be powerful sources of information, there is clearly a need for additional data with which tools such as the LANDFIRE map layers could be strengthened. In the interim, information on the relative differences in fuel loadings from LANDFIRE-represented data may be useful to managers who are tasked with quantifying emissions for fire management planning. Using all of these resources will aid in generating more accurate emissions estimates in a climate where regulatory pressure and the need to accurately represent potential emissions from fire are increasing.

\section{ACKNOWLEDGEMENTS}

The authors would like to thank the National Wildfire Coordinating Group's Fuels Committee for providing funding to the National Interagency Fuels Technology Transfer, which made this research possible. Additional thanks go to the USDA Forest Service for providing measured fuel loading, and to forestry technician P. Fekety for data preparation. 


\section{LITERATURE CITED}

Agee, J.K. 1996. Achieving conservation biology objectives with fire in the Pacific Northwest. Weed Technology 10: 417-421.

AirFire Team. 2015. BlueSky Modeling Framework homepage. <http://www.airfire.org/bluesky/>. Accessed 10 September 2015.

Albini, F.A., and E.D. Reinhardt. 1997. Improved calibration of a large fuel burnout model. International Journal of Wildland Fire 7: 21-28. doi: 10.1071/WF9970021

Bartlett, M.S. 1937. Properties of sufficiency and statistical tests. Proceedings of the Royal Society of London Series A 160: 268-282. doi: 10.1098/rspa.1937.0109

Brown, J. 1974. Handbook for inventorying downed woody material. USDA Forest Service General Technical Report INT-16, Intermountain Forest and Range Experiment Station, Ogden, Utah, USA.

Brown, J. 1981. Bulk densities of nonuniform surface fuels and their application to fire modeling. Forest Science 27: 677-683.

Brown, J.K., R.D. Oberheu, and C.M. Johnston. 1982. Handbook for inventorying surface fuels and biomass in the Interior West. USDA Forest Service General Technical Report INT-129, Intermountain Forest and Range Experiment Station, Ogden, Utah, USA.

Comer, P., D. Faber-Langendoen, R. Evans, S. Gawler, C. Josse, G. Kittel, S. Menard, M. Pyne, M. Reid, K. Schulz, K. Snow, and J. Teague. 2003. Ecological systems of the United States: a working classification of US terrestrial systems. NatureServe, Arlington, Virginia, USA.

Cooper, S.V., K.E. Neiman, and D.W. Roberts. 1991. Forest habitat types of northern Idaho: a second approximation. USDA Forest Service, General Technical Report INT-236, Intermountain Forest and Range Experiment Station, Ogden, Utah, USA.

Drury, S.A., N. Larkin, T.T. Strand, S. Huang, S.J. Strenfel, E.M. Banwell, T.E. O'Brien, and S.M. Raffuse. 2014. Intercomparison of fire size, fuel loading, fuel consumption, and smoke emissions estimates on the 2006 Tripod Fire, Washington, USA. Fire Ecology 10 (1): 56-82. doi: 10.4996/fireecology.1001056

Dunnett, C.W. 1980. Pairwise multiple comparisons in the unequal variance case. Journal of the American Statistical Association 75: 796-800. doi: 10.1080/01621459.1980.10477552

Falkowski, M.J., J.S. Evans, S. Martinuzzi, P.E. Gessler, and A.T. Hudak. 2009. Characterizing forest succession with LiDAR data: an evaluation for the Inland Northwest, USA. Remote Sensing of Environment 113: 946-956. doi: 10.1016/j.rse.2009.01.003

FERA [Fire Environment Research Applications] Team. 2014. Fuel and fire tools: user guide. $<$ http://www.fs.fed.us/pnw/fera/research/smoke/consume/index.shtml $>$. Accessed 28 September 2015.

Fox, J., S. Weisberg, D. Adler, D. Bates, G. Baud-Bovy, S. Ellison, D. Firth, M. Friendly, G. Gorjanc, S. Graves, R. Heiberger, R. Laboissiere, G. Monette, D. Murdoch, H. Nilsson, D. Ogle, B. Ripley, W. Venables, and A. Zeileis. 2014. Package 'car.' Version 2.0-21. <http:// cran.r-project.org/web/packages/car/car.pdf>. Accessed 13 August 2014.

FRAMES [Fire Research and Management Exchange System]. 2015. Fire Research and Management Exchange System homepage. <https://www.frames.gov/>. Accessed 8 September 2015. 
French, N.H.F., W.J. de Groot, L.K. Jenkins, B.M. Rogers, E. Alvarado, B. Amiro, B. de Jong, S. Goetz, E. Hoy, E. Hyer, R. Keane, B.E. Law, D. McKenzie, S.G. McNulty, R. Ottmar, D.R. Pérez-Salicrup, J. Randerson, K.M. Robertson, and M. Turetsky. 2011. Model comparisons for estimating carbon emissions from North American wildland fire. Journal of Geophysical Research 116(G4): G00K05. doi: 10.1029/2010jg001469

Hamby, D.M. 1994. A review of techniques for parameter sensitivity analysis of environmental models. Environmental Monitoring and Assessment 32: 135-154. doi: 10.1007/BF00547132

Hann, W., D. Hamilton, C. Winne, C. Frame, C. McNicoll, C. Ryan, J. Herynk, B. Hanus, J. Caratti, J. Gibson, and L. Hamilton. 2012. LANDFIRE Refresh 2001 and 2008, compared with LANDFIRE National, for biophysical settings, fuel loading models, fire regime layers, and fire behavior and effects-methods, results, and recommendations for the contiguous lower 48 states and Alaska. Version-April 5, 2012. Systems for Environmental Management LLC, Missoula, Montana, USA.

Hardy, C.C., and S.F. Arno, editors. 1996. The use of fire in forest restoration. USDA Forest Service General Technical Report INT-GTR-341, Intermountain Research Station, Ogden, Utah, USA.

Hardy, C.C., R.D. Ottmar, J.L. Peterson, J.E. Core, and P. Seamon. 2001. Smoke management guide for prescribed and wildland fire, 2001 edition. National Wildfire Coordination Group PMS 420-2, Boise, Idaho, USA.

Hille, M.G., and S.L. Stephens. 2005. Mixed conifer duff consumption during prescribed fires: tree crown impacts. Forest Science 51: 417-424.

Hoffman, F.O., and R.H. Gardner. 1983. Evaluation of uncertainties in environmental radiological assessment models. Pages 11-1 to 11-50 in: J.E. Till and H.R. Meyer, editors. Radiological assessments: a textbook on environmental dose assessment. US Nuclear Regulatory Commission Report No. NUREG/CR-3332, Washington, D.C., USA.

Hudak, A.T., E.K. Strand, L.A. Vierling, J.C. Byrne, J.U.H. Eitel, S. Martinuzzi, and M.J. Falkowski. 2012. Quantifying aboveground forest carbon pools and fluxes from repeat LiDAR surveys. Remote Sensing of Environment 123: 25-40. doi: 10.1016/j.rse.2012.02.023

IFTDSS [Interagency Fuels Treatment Decision Support System]. 2015. Interagency Fuels Treatment Decision Support System homepage. <http://iftdss.sonomatech.com/>. Accessed 8 September 2015.

Keane, R.E. 2013. Describing wildland surface fuel loading for fire management: a review of approaches, methods and systems. International Journal of Wildland Fire 22: 51-62. doi: 10.1071/WF11139

Keane, R.E., and L.J. Dickinson. 2007 The photoload sampling technique: estimating surface fuel loadings from downward-looking photographs of synthetic fuelbeds. USDA Forest Service General Technical Report RMRS-GTR-190, Rocky Mountain Research Station, Fort Collins, Colorado, USA.

Keane, R.E., K. Gray, V. Bacciu, and S. Leirfallom. 2012. Spatial scaling of wildland fuels for six forest and rangeland ecosystems in the northern Rocky Mountains, USA. Landscape Ecology 27: 1213-1234. doi: 10.1007/s10980-012-9773-9

Keane, R.E., J.M. Herynk, C. Toney, S.P. Urbanski, D.C. Lutes, and R.D. Ottmar. 2013. Evaluating the performance and mapping of three fuel classification systems using Forest Inventory and Analysis surface fuel measurements. Forest Ecology and Management 305: 248-263. doi: 10.1016/j.foreco.2013.06.001 
Kobziar, L., J. Moghaddas, and S. Stephens. 2006. Tree mortality patterns following prescribed fires in a mixed conifer forest. Canadian Journal of Forest Research 36: 3222-3238. doi: 10.1139/x06-183

LANDFIRE [Landscape Fire and Resource Management Planning Tools] Team. 2014a. Homepage for the LANDFIRE Project. <http://landfire.gov/>. Accessed 19 September 2014.

LANDFIRE [Landscape Fire and Resource Management Planning Tools] Team. 2014b. Frequently asked questions - at what scale should LANDFIRE data be used? <http:/www.landfire.gov/faq.php?faq id=263\&sort id=1>. Accessed 12 February 2015.

Lau, M.K. 2013. DTK-package Dunnett-Tukey-Kramer pairwise multiple comparison test adjusted for unequal variances and unequal sample sizes. $<$ http://127.0.0.1:12731/library/DTK/ html/DTK-package.html>. Accessed 13 August 2014.

Liu, J.C., G. Pereira, S.A. Uhl, M.A. Bravo, and M.L. Bell. 2015. A systematic review of the physical health impacts from non-occupational exposure to wildfire smoke. Environmental Research 136: 120-132. doi: 10.1016/j.envres.2014.10.015

Lutes, D.C. 2012. First Order Fire Effects Model mapping tool: FOFEM Version 6.0 user's guide. USDA Forest Service, Rocky Mountain Research Station, Fort Collins, Colorado, USA. <https://www.frames.gov/rcs/15000/15530.html>. Accessed 28 September 2015.

Lutes, D.C., R.E. Keane, and J.F. Caratti. 2009. A surface fuel classification for estimating fire effects. International Journal of Wildland Fire 18: 802-814. doi: 10.1071/WF08062

Martinuzzi, S., L.A. Vierling, W.A. Gould, M.J. Falkowski, J.S. Evans, A.T. Hudak, and K.T. Vierling. 2009. Mapping snags and understory shrubs for a LiDAR-based assessment of wildlife habitat suitability. Remote Sensing of Environment 113: 2533-2546. doi: 10.1016/j. rse.2009.07.002

McDonough, T. 2003. Wildfire torches homes and acreage; flames destroy five residences near Viola. Moscow-Pullman Daily News. 31 July 2003. <http://dnews.com/local/wildfire-torches-homes-acreage-flames-destroy-five-residences-near-viola/article_a9ed25d0-f25a-5ffcbbea-6c5a92a2e405.html>. Accessed 12 September 2015.

McKenzie, D., N.H.F. French, and R.D. Ottmar. 2012. National database for calculating fuel available to wildfires. Eos Transactions American Geophysical Union 93: 57-58. doi: 10.1029/2012EO060002

Melvin, M.A. 2012. 2012 National prescribed fire use survey report. Coalition of Prescribed Fire Councils Inc. <www.stateforesters.org/sites/default/files/publication-documents/2012_ National_Prescribed_Fire_Survey.pdf $>$. Accessed 11 August 2015.

NWCG [National Wildfire Coordinating Group]. 2014. Interagency prescribed fire planning and implementation procedures guide. Boise, Idaho, USA. <http://www.nwcg.gov/pms/RxFire/ pms484.pdf>. Accessed 4 February 2015.

Ottmar, R.D., D.V. Sandberg, C.L. Riccardi, and S.J. Prichard. 2007. An overview of the Fuel Characteristic Classification System - quantifying, classifying, and creating fuelbeds for resource planning. Canadian Journal of Forest Research 37: 2383-2393. doi: 10.1139/X07077

Ottmar, R.D., R.E. Vihnanek, and C.S. Wright. 2003. Stereo photo series for quantifying natural fuels in the Americas. Poster and extended abstract. Page 122 in: J.S. Kush, editor. Proceedings of the Fourth Longleaf Alliance Regional Conference-longleaf pine: a southern legacy rising from the ashes. The Longleaf Alliance, 17-20 November 2002, Southern Pines, North Carolina, USA.

Prichard, S.J., R.D. Ottmar, and G.K. Anderson. 2005. Consume user's guide, version 3.0. USDA Forest Service, Pacific Wildland Fire Sciences Laboratory, Seattle, Washington, USA. 
Raymond, C.L., and D.L. Peterson. 2005. Fuel treatments alter the effects of wildfire in a mixed-evergreen forest, Oregon, USA. Canadian Journal of Forest Research 35: 2981-2995. doi: $10.1139 / \mathrm{x} 05-206$

Reinhardt, E.D. 2003. Using FOFEM 5.0 to estimate tree mortality, fuel consumption, smoke production and soil heating from wildland fire. Page P5.2 in: Proceedings of the Second International Wildland Fire Ecology and Fire Management Congress and Fifth Symposium on Fire and Forest Meteorology. American Meteorological Society, 16-20 November 2003, Orlando, Florida, USA. <http://ams.confex.com/ams/pdfpapers/65232.pdf>. Accessed 20 October 2014.

Reinhardt, E.D., J.K. Brown, W.C. Fischer, and R.T. Graham. 1991. Woody fuel and duff consumption by prescribed fire in northern Idaho mixed conifer logging slash. USDA Forest Service Research Paper INT-443, Intermountain Research Station, Ogden, Utah, USA.

Rollins, M.G. 2009. LANDFIRE: a nationally consistent vegetation, wildland fire, and fuel assessment. International Journal of Wildland Fire 18: 235-249. doi: 10.1071/WF08088

Rothman, H.K. 2005. A test of adversity and strength: wildland fire in the national park system. US Department of the Interior, Washington, D.C., USA. <http:/www.nps.gov/fire/wildland-fire/resources/documents/wildland-fire-history.pdf $>$. Accessed 19 June 2015.

R-Project. 2013. Homepage of The R Project for statistical computing. < http://www.r-project. org/>. Accessed 20 October 2014.

Sikkink, P.G., and R.E. Keane. 2008. A comparison of five sampling techniques to estimate surface fuel loading in montane forests. International Journal of Wildland Fire 17: 363-379. doi: 10.1071/WF07003

Smith, W.B., and G.J. Brand. 1983. Allometric biomass equations for species of herbs, shrubs, and small trees. USDA Forest Service Research Note NC-299, North Central Forest Experiment Station, St. Paul, Minnesota, USA.

USDA FS [US Department of Agriculture Forest Service]. 2008. 2008 Fire management plan Clearwater and Nez Perce forests. <http://gacc.nifc.gov/nrcc/dc/idgvc/Zone_Info/ ClearNezFMP_08final.doc>. Accessed 8 September 2015.

USDI NPS [US Department of Interior National Park Service]. 2005. Olympic National Park fire management plan. <http://www.nps.gov/olym/learn/management/upload/FINAL-OLYMFMP-11212005.pdf $>$. Accessed 9 September 2015.

US EPA [US Environmental Protection Agency]. 1990. Clean Air Act amendments. <http:// www.epa.gov/air/caa/text.html>. Accessed 20 October 2014.

US EPA [US Environmental Protection Agency]. 2015. Technology transfer network national ambient air quality standards (NAAQS). <http://www3.epa.gov/ttn/naaqs/criteria.html >. Accessed 29 September 2015.

van Wagtendonk, J.W. 2007. The history and evolution of wildland fire use. Fire Ecology 3 (2): 3-17. doi: 10.4996/fireecology.0302003

Ward, D.E., J. Peterson, and W.M. Hao. 1993. An inventory of particulate matter and air toxic emissions from prescribed fires in the USA for 1989. Proceedings of the 86th Annual Meeting and Exhibition. Air and Waste Management Association, 13-18 June 1993, Denver, Colorado, USA.

WFDSS [Wildland Fire Decision Support System]. 2015. Wildland Fire Decision Support System homepage. <http://wfdss.usgs.gov/wfdss/WFDSS_Home.shtml>. Accessed 8 September 2015 . 
Woodall, C., and V. Monleon. 2008. National inventories of dead and downed forest carbon stocks in the United States: opportunities and challenges. Forest Ecology and Management 256: 221-228. doi: 10.1016/j.foreco.2008.04.003

Woudenberg, S.W., B.I. Conkling, B.M. O’Connell, E.B. LaPoint, J.A. Turner, and K.I. Waddell. 2010. The Forest Inventory and Analysis database: database description and user's manual version 4.0 for Phase 2. USDA Forest Service General Technical Report RMRS-GTR-245, Rocky Mountain Research Station, Fort Collins, Colorado, USA.

Youngblood, A., C.S. Wright, R.D. Ottmar, and J.D. McIver. 2008. Changes in fuelbed characteristics and resulting fire potentials after fuel reduction treatments in dry forests of the Blue Mountains, northeastern Oregon. Forest Ecology and Management 255: 3151-3169. doi: 10.1016/j.foreco.2007.09.032 